\title{
The Role of Zakat in Establishing Social Welfare and Economic Sustainability: The Case of Saudi Arabia
}

\author{
Aysha N. Al-Salih ${ }^{1}$ \\ ${ }^{1}$ College of Business Administration, Princess Nora Bint Abdulrahman University, Riyadh, Saudi Arabia \\ Correspondence: Aysha N. AlSalih, College of Business Administration, Princess Nora Bint Abdulrahman \\ University, Riyadh, 11671, Kingdom of Saudi Arabia.
}

Received: August 14, 2020

Accepted: September 20, 2020

Online Published: November 30, 2020

doi:10.5430/ijfr.v11n6p196

URL: https://doi.org/10.5430/ijfr.v11n6p196

\begin{abstract}
Much recent literature has studied the role of Zakat in establishing social welfare and economic sustainability. It is believed that Zakat is among the most important systems for Muslims: indeed, it enables the wealthy and rich to purify their hearts from greed by giving a part of their wealth to the needy. Therefore, Zakat redistributes income and wealth, plays an important role in poverty alleviation, and contributes to social welfare and economic sustainability. This study discusses the role of Zakat in establishing social welfare and economic sustainability by reviewing theoretical and empirical studies. This prior research is then extended by examining the historical development of Zakat and the structure of Zakat accounting method in Saudi Arabia. This study is significant in creating awareness about Zakat's role and its impact on the social life of a society. The researcher employs qualitative research methods, reviewing traditional and contemporary Islamic sources to explicate the significance of Zakat as an institution, and elaborate its impact on social life in line with the main theme of the study. The topic of Zakat is one that has received increased attention by researchers interested in Muslim values, social welfare, economic sustainability, and accounting. However, little research has been produced on the intersections of these four topics in the specific context of Saudi Arabia. The overall findings show that Zakat has a positive impact on social welfare and economic sustainability in Saudi Arabia.
\end{abstract}

Keywords: accounting, economic sustainability, Saudi Arabia, social welfare, Zakat

\section{Introduction}

Zakat is the third pillar of Islam, ordered by Allah (swt) and urged by the Prophet Muhammad (pbuh). Ibrahim, (2015) defines Zakat as compulsory alms paid by rich Muslims upon acquiring a certain amount of wealth called nisab, which is given to a particular category of people called asnaf (437). The collection of Zakat is affirmed by the Sharia law, the Quran and Sunnah, an obligation that all wealthy Muslims have to the poor. Allah says: "Of their wealth, take alms, that so thou mightiest purify and sanctify them; and pray on their behalf. Verily thy prayers are a source of security for them: And Allah is One Who heareth and knoweth" (Al-Quran. Al-Taubah 9:103). In this sense, Zakat plays an integral part in the Islamic economic system. Thus, Zakat redistributes income and wealth, plays an important role in poverty alleviation, and contributes to social welfare and economic sustainability. Zakat is designed to establish a community in which every citizen is devoted to social justice, equity, and freedom (Ibrahim, 2015). By recognising that one's wealth is a gift from Allah (swt) and giving away a portion of it to others, a Muslim purifies the rest of his or her wealth from greed and miserliness.

Aliyu et al. 2016, argues that [Zakat] could differ significantly from products in the conventional tax system. Zakat is a complex system because it adheres to Sharia principles, it, therefore, requires a better understanding of the precise sources of any income and the treatment of taxes (138). Zakat is an obligatory right for those in need. It is collected at the end of every Hijri year; in the Islamic calendar, so givers can earn the mercy of Allah (swt), purify one's self and money, and to support others in the community. Taxation can be defined as a compulsory payment to a government based on the holdings of a tax base (Mikesell, 2003). Although different types of taxes exist, Zakat is one of the most prominent among them in the Muslim world (138).

The main objective of this paper is to discuss the role of Zakat in establishing social welfare and economic sustainability by reviewing theoretical and empirical studies. This prior research is then extended by examining the historical development of Zakat and the structure of Zakat accounting method in Saudi Arabia. 


\section{The Relationship of Zakat to Social Welfare and Economic Sustainability}

Zakat is a moral obligation that wealthy Muslims have to the poor and needy, and failure to pay it is considered unethical behaviour. Governments of Islamic countries, or countries with large Muslim populations, regulate the Zakat system through authoritative bodies and ensure that lump sums are paid through the appropriate means. As such, Zakat is binding even if there is no legitimate government. According to Pryor (1985), the Islamic system of economy is a particular construct that members of the Islamic faith follow. Zalloom (1988) states six areas of expenditure that the Bait ul-Mal (the treasury in Islam) is obliged to spend upon if insufficient funds are available, with tax including Zakat imposed upon Muslims to meet the required expenditure: 1- The expenditure upon Jihad and what is necessary for this purpose is obligatory upon Muslims by wealth and person. 2- Expenditure on military industries: an Islamic State is obliged to establish military and other associated industries to enable the manufacturing of the latest and most sophisticated weapons and equipment for the armed forces. 3- Spending on the poor, needy and wayfarers: this is an obligation whether there are funds in the Bait ul-Mal or not. If there are no funds in the Bait ul-Mal then the obligation transfers to Muslims. 4- Expenses for the salaries of soldiers, civil servants, judges, teachers, and the like who provide services for the benefit of the Ummah. 5- Expenses due in the form of services and caring of the Ummah. These expenses are spent on utilities whose existence is considered a necessity (Dharura) in the sense that in their absence harm would result to the Ummah e.g. public roads, schools, universities, hospitals, mosques, water supplies, and similar services. 6- Expenditure upon emergencies, such as famines, earthquakes, floods, and enemy attacks (pp 114-119).

From this perspective, Zakat improves the economic system and provides a means of sustaining governance. Al-Suhaibani (1990) analyses the impact of Zakat on consumption, investment, employment, economic growth, inflation, and economic stability. The study also discusses the impact of Zakat on resource's allocation and distribution of wealth and income. Two new topics; Zakat incidence and Zakat buoyancy were introduced. It is believed that these topics were not addressed prior to this study by any Islamic economics researchers. The study finds that Zakat usually increase consumption and investment, especially if the economy is suffering from unemployment and thus raises the level of utilization of all economic resources available in the economy.

Guermat et al. (2003) argues that Zakat has been given little attention in Islamic economics literature and both theoretical and empirical studies are scarce. The paper attempts to initiate discussion on the realities of the practice of Zakat in the Muslim world. A sample of 159 respondents from four Gulf Cooperation Council (GCC) countries; Kuwait, Bahrain, Saudi Arabia, and the United Arab Emirates concerning the evaluation, collection, and payment of Zakat. This paper confirms that Zakat is a relationship between the person and God. The overall result indicates that most of the respondents nominated the country's Authority of Zakat as a suitable body for the collection of Zakat. The findings of the paper show that respondents are mostly in favour of paying the whole amount of Zakat to the collecting institution. Many respondents favour giving a greater role to charitable organisations in collecting and distributing Zakat. Finally, there was also some support for allowing a certain proportion of Zakat to be paid by the Zakat payers directly.

Ibrahim (2015) sheds light on the role of Zakat in establishing social welfare and economic development. His study suggests that Zakat should be institutionalised and properly managed by Islamic states and various Muslim communities, with the use of charity organisations helpful in places where there is no Islamic state. Ibrahim (2015) also argues that local Zakat committees should be constituted at lower levels, and all Zakat activities overseen by Sharia committees which should be responsible for ensuring Sharia compliance and the avoidance of any misapplications. His study further recommends, that Muslim scholars and Khateebs (religious scholars) should work together and use electronic and print media to raise people's awareness about the importance of Zakat and its social, moral, economic, and spiritual impact on society.

Abdelbaki (2015) identifies Zakat an Islamic social security system as well as an Islamic socioeconomic system that aims to reduce and minimize the gap between the poorer and the richer in Islamic societies. He employs the Generalized Method of Moments (GMM) panel analysis for the period 2001-2012 of 14 Malaysian states to examine the impact of Zakat expenditure on income inequality and poverty in Malaysia. The results indicate, while Zakat has no significant effect on income inequality, Zakat significantly reduces both poverty incidence and hardcore poverty. The study also suggests Zakat institutions funds to employ Had-Kifayah Zakat distribution model.

From a similar perspective, Aliyu et al. (2016) studies the significance of Islamic taxation in Nigerian economic development, taking into account the major role that ethics plays in Islam. The study shows that even though several tax reforms had been conducted, dating back to before Nigerian independence, the impact of the revenue generated had not been felt. The study examines Northern Nigeria, an area in which over 50\% of the population are Muslims. It 
argues that bringing back the old system of taxation, or using the Islamic systems of taxation that have been applied in other Islamic countries, would undoubtedly assist the region and thereby improve the economic condition of the poor. Aliyu et al. (2016) recommends that the Northern Nigerian state government should start working out how best to handle Islamic tax collection, especially in response to the country's worsening economic conditions as a result of the global fall in oil prices. The study also recommends that this would be achievable provided that the government genuinely intended to assist the poor based on Islamic requirements on the utilisation of taxes.

Oran (2016) believes that the weakness of Muslim countries economic and social performance lies in public budgets' deficits. His study attempts to show the possibility of applying the Islamic economic thought to effectively improving human development in Muslim countries. Oran's (2016) gradual approach proposes a project to activate and direct the role of Zakat to enhance human development. He suggests that activating Zakat institution by employing its funds on behalf of beneficiaries enables wealth creation. Furthermore, he recommends that the growth in wealth should be used to combat hunger and poverty that will necessarily lead to improve human development. Therefore, the activation of Zakat role would not only serve the poor, but it will also strengthen the economy of the affected country.

Shaikh and Ismail (2017) explore the potential of the institution of Zakat to meet development challenges in the Muslim world. As part of this studied, they examine a wide variety of institutions to identify which had the greatest potential for driving development forward. Their findings suggest that Zakat can play an important role in meeting sustainable development goals related to poverty, hunger, global health and well-being, quality education, decent work, economic growth, and income inequality.

On the contrary, Khasandy and Badrudin's (2019) study confirms that Zakat in Indonesia does not influence economic growth and the welfare of society. Besides that, Indonesia, as a developing country, has a negative value in terms of the Human Development Index (HDI) and the GINI index, but a positive value in terms of the percentage of poor people. These results came from an examination of the influence of Zakat on Indonesian economic growth and welfare, and investigating whether the theory of planned behaviour influences Zakat payments. Three indicators were used HDI, GINI Index, and the percentage of poor people.

As it is widely believed by economists that Zakat does not affect macroeconomy since 2.5 percent is perceived insignificant. This belief leads to a high curiosity about the impact of Zakat distribution in Indonesia. Suprayitno (2020) studies the impact of Zakat distribution on macroeconomic in 5 Indonesian states and uses ECM analysis. This study finds that Zakat has a significant and positive relationship with economic growth. The results of the ECM analysis show that the distribution of Zakat positively influences on economic growth. The long-run elasticity of Zakat variable is positive and significant.

Bilo et al. (2020) discusses the role of Zakat funds in the provision of social protection in the Middle East and North Africa region, focusing on the examples of Jordan and Sudan. The purpose of their paper was to assess different modalities of Zakat in two countries, where it is regulated in some form by the state. Bilo et al.'s findings were based on a desk review of academic, peer-reviewed literature, reports published by international organisations, and information provided online by governments and national Zakat Funds. Their choice to focus on Jordan and Sudan was partially motivated by the availability of literature on these countries in English and Arabic. Their study found that the extent to which Zakat can be used to finance social protection measures varies not only in the way it is collected and administered, but also in response to each respective country's geographic and political conditions. In Sudan, Zakat is mandatory and reaches proportionally more households than in Jordan. While the Quran establishes the eight categories for those who should receive Zakat, the selection in both countries is at the discretion of the funds' administrators.

The literature on the role of Zakat in establishing social welfare and economic sustainability confirms that Zakat redistributes income and wealth, plays an important role in poverty alleviation, and contributes to social welfare and economic sustainability.

\section{The Historical Development of Zakat in the Kingdom of Saudi Arabia}

Islamic countries establish social solidarity systems through the imposition of Zakat on all Muslims. Zakat is a Sharia obligation and one of the pillars of Islam. It achieved its legitimacy, social, and economic purpose after being first applied during the second year of Hijra (immigration). After that, a neglection in the collection of Zakat was seen throughout Islamic history, to such an extent that it almost became forgotten (Almunif, 1996, Al-Hweiml, 2013 and GAZT, 2019). Saudi Arabia gave renewed attention to Zakat around the time that the Kingdom was unified in 1932. This resulted in issuing a Royal Decree No. (178634/28/2/) dated 29/06/1370H (corresponding to 6 April 1951) 
for levying of Zakat (GAZT, 2019). Some taxation was imposed; however, this was not welcomed by Saudi citizens. Grievances were filed and they were accepted by the government. Therefore, Saudis became exempt from paying taxes.

At the beginning of Zakat enforcement, there were no specialised institutions that monitored the system and ensured accountability. As such, The Ministry of Finance then took the initiative to issue a proper structure to implement the Zakat system. Hence, a special authority was established within the ministry to ensure the issuance and collection of Zakat from trade and business owners. This resulted in the ministry issuing Zakat executive regulations consisting of twenty articles. The General Authority for Zakat and Income Tax (GAZT) was established in 1951, with the primary function of collecting the Zakat of trade from both nationals of the Kingdom of Saudi Arabia and resident citizens of the Gulf Cooperation Council (GCC) countries. The GAZT was first based in Jeddah, but moved to Riyadh shortly afterwards (Al-Hweiml, 2013 and GAZT, 2019).

Saudi Arabia has a population of approximately over 34 million, in which 97 percent are Muslims. In 2019, Saudi Arabia's GNI per capita was US\$22,850 which shows an increase of a 5.79\% from 2018. Although Saudi Arabia is a rich country and expected to reach the highest domestic product (GDP) of US\$745,00 billion by the end of 2020 as compared to other high-income Islamic countries, the low GNI per capita indicates that a relative poverty issue does exists. Various non-Saudis are treated as Saudis for the purposes of Zakat. That is to say, that individuals covered by the pastoral activities of any of the other GCC countries, whether male or female, adult, underage or interdicted, who carry out their activities within the Kingdom of Saudi Arabia are subject to Zakat. Zakat is also applied to businesses and funds registered in the Kingdom or in any of the GCC countries. Zakat is levied on capitals and their yields, and on all imports, profits, and gains of individuals and companies from practicing trade, industry, personal business, property or from cash holdings of any kind, including financial and commercial transactions and selling of shares (GAZT, 2019). The Zakat base includes many elements that affect its value other than profits. After determining the adjusted and accepted profit from the GAZT, some elements are added from the statement of financial position in the period in which Zakat is due, and items that are exempt from Zakat are deducted.

In terms of distributions, Zakat is collected from the "Zakat" portal and application for individuals disbursed to all beneficiaries of social security. Then the fund is transferred to the Saudi Arabian Monetary Agency (SAMA), which is the central bank of Saudi Arabia. SAMA then transfers the funds to the Social Insurance Agency of the Ministry of Human Resource and Social Development (HRSD) for distributions. The eligible groups of Zakat are: orphans, the incapable of work, elderly, unsupported families such as (widowers and orphans, divorced families with children, families of prisoners, abandoned families, the family of the absent and the missing, the family of the drug addict), and women who have no supporter, such as widowed, divorced, abandoned alone and the wife of a prisoner, and of unknown parents who are over the age of 18 years (The Ministry of Human Resource and Social Development, 2020). The inclusion of insurance beneficiaries takes place according to conditions and controls set by the provisions of the system and its executive regulations, such as: the economic, social and health status. Each case is then studied and verified through the automated search and field research system. HRSD embodies the values of social solidarity between members of society and among deserving groups according to an existing strategic partnership between the Ministry and GAZT. The HRSD budget for 2020 is SR72,282,084,000. The latest statistics show that social security beneficiaries reached 884,063 and the largest segment of beneficiaries were female of 537,066 (HRSD, 2020). From this angle, it can be concluded that Zakat plays an important role in establishing social welfare in Saudi Arabia that reflects positively on its economy.

\subsection{Zakat Calculation}

There are two ways to calculate the Zakat base, the first depends on the uses of funds, while the second depends on the source of funds. Firstly, there is the working capital method (uses of funds), which is the direct way to calculate the Zakat base, that is, the way that takes the Zakat of funds and resolves what should not be recommended directly. In the context of this application of the rule of jurisprudence, Abu Obeid Maimon ibn Mehran states that, If you are authorised to contribute to Zakat, you should see what you have of cash or offer for sale value of cash, plus the debt in the solvency - then subtract what you have of the debt. Zakat is what is left. Hence, Zakat will be from the funds intended for sale and purchase (Essa, and Aljundi, 1985).

The funds intended for use and contribution to production are not immediately subject to Zakat. Instead, Zakat is applied to revenues. It is worth mentioning, that this method is not used by the GAZT in the Kingdom, but it must be explained so it can be compared with the first method of Zakat calculation; uses of funds. The so-called working capital method is derived from this concept, in which current liabilities are subtracted from current assets, to arrive at the public capital, which represents here the Zakat base for Zakat of trade offers (Al-Hweiml, 2013). 
The second method to be considered is that of property rights (sources of funds): This is the indirect way to calculate the Zakat base, which includes in the base many influential elements other than profits. After the GAZT determines the adjusted and acceptable profit, some elements are added from the statement of financial position from the period in which Zakat is due, and those elements that do not apply are deducted. This is done indirectly so that the sources of funds are used to identify the Zakat base, rather than the uses of the funds as prescribed by Sharia.

The following table shows the elements that are added to the Zakat base, followed by the elements that are deducted from the Zakat base as defined by the Saudi Zakat Regulations, Zakat executive regulations, fatwas and ministerial decisions issued in this regard, as supported by circulars and clarifications issued by the GAZT (GAZT, 2019 and Al-Hweiml, 2013).

Table 1. Elements that are added/deducted to the Zakat base

\begin{tabular}{|c|c|}
\hline Added Elements & Deducted Elements \\
\hline Equity capital & Adjusted net loss \\
\hline Adjusted annual net profit & Net fixed assets \\
\hline Retained earnings for previous years & Fixed assets spare parts \\
\hline Provisions and reserves & $\begin{array}{l}\text { Materials and missions of electricity companies } \\
\text { and pilgrims transport companies }\end{array}$ \\
\hline Profit under distribution & Advances for the purchase of fixed assets \\
\hline $\begin{array}{l}\text { Current account credit balance of the business owner } \\
\text { or partners }\end{array}$ & Construction in progress \\
\hline Loans & The carry-over loss from previous years adjusted \\
\hline Government subsidy & $\begin{array}{l}\text { Balance of establishment and pre-operating } \\
\text { expenses }\end{array}$ \\
\hline The commercial debts of the taxpayer to others & Investments in other facilities \\
\hline \multirow[t]{2}{*}{ Amounts collected for goods under delivery } & Investing in government bonds \\
\hline & $\begin{array}{l}\text { Current account balance of the business owner or } \\
\text { partners }\end{array}$ \\
\hline
\end{tabular}

Source: (GAZT, 2019)

\subsection{Zakat Accounting}

All Zakat taxpayers must keep the following commercial books: general journal, general ledger, inventory, in addition to the necessary accounting records required for the precise determination of Zakat. These books and records must be maintained in the Kingdom of Saudi Arabia in Arabic, alongside the documents that prove their validity, and the statements and explanations they interpret. The commercial book system also obliges all taxpayers, whether foreigners or Saudis and whether individuals or companies, to keep their books and submit their accounts in Arabic. Should any taxpayers disagree by holding their business book in a language other than Arabic and presenting their statutory accounts in Arabic on the basis of these books, GAZT shall accept these accounts and not waste them and link the tax or Zakat accordingly after the taxpayer translates and authenticates his books from his legal accountant and submits a copy (SOCPA, 2016).

\subsubsection{Zakat Accounting Standard}

The objective of this standard is to determine the measurement, presentation, and disclosure requirements for Zakat expenses in financial statements. This is so that the financial statements present fairly the financial position of the entity and its results (SOCPA, 2016). This standard specifies the requirements for measuring and presenting Zakat expenses and disclosing them in the financial statements of profit-making establishments that are legally obligated to pay Zakat by the General Authority for Zakat and Income Tax. This standard does not include the determination of the method of calculating Zakat, which is determined in the light of the rules and regulations (SOCPA, 2016). 
Zakat expenditure for each financial period shall be measured and recorded under the provisions of the Zakat obligation in the Kingdom. The provision for Zakat is settled in the financial year in which the final assessment is approved. Any difference between the Zakat provision and the final assessment is recognized under the requirements of IAS 8 Accounting Policies, Changes in Accounting Estimates and Errors. Zakat expenses for the period must be presented in a separate line item in the income statement before profit or loss (SOCPA, 2016). The financial statements disclose the following:

-Accounting policy used in the treatment of Zakat.

-Detailed elements and amounts of the main positive and negative Zakat base.

-Zakat provision balance at the beginning of the annual period, additions, and exclusions made during that period and the balance at the end of the period.

-The amount of the final assessment approved for each annual period and the amount of the difference between it and the Zakat provision for that period and a summary of its nature.

-The years for which Zakat has not been definitively linked, the reasons for this and the party before it, if any, between the establishment and the General Authority for Zakat and Income Tax, and the amount in dispute (SOCPA, 2016).

This revised standard must be applied in conjunction with the transition to International Standards which commence (in accordance with the entity's status as of 1 January 2017) (SOCPA, 2016).

\section{Discussion and Conclusion}

The topic of Zakat is one that has received increasing attention from researchers interested in Muslim values, social welfare, economic sustainability, and accounting. Zakat is one of the five pillars of Islam; a religious obligation for all Muslims who meet the necessary standards of wealth. The system of Zakat is applied in Islamic countries or in places with large Muslim populations. Zakat in Saudi Arabia is administered by the Ministry of Human Resource and Social Development and governed by the General Authority for Zakat and Income Tax. Saudi Arabia implemented the compulsory Zakat payment law, as Saudi individuals and companies except for several exempted ones must pay Zakat at the rate of 2.5 percent from the assessable amount. The latest statistics show that social security beneficiaries reached 884,063 (HRSD, 2020).

Zakat is seen to be one of the most important systems of both economic sustainability and social welfare because its main objectives are to develop balanced socio-economic growth and to purify one's soul and wealth. The impact of Zakat on economics can be discussed and divided into two sections: First, the impact on microeconomics. Considering the fact that Zakat payers are not responsible for disbursing Zakat to beneficiaries. Also, the country has the means of control and interference that enable it to prevent any individual attempt to distribute Zakat. This impact economies in a way that the collection of Zakat is compared to an indirect state of stability to raise operating efficiency. On the other hand, it is noticed that the authority/establishment that transfers Zakat may cause partial inflation; the size of which depends on the importance of the transferring facility within the sector, which inevitably leads to less operation efficiency while inflation is not desirable in any case. In addition, an economic impact of collecting Zakat on the supply of products in a particular sector is expected. This can be seen in three ways: assuming that all establishments when it operates efficiently (1) Zakat stabilises in this case on the firm's profits, so its equilibrium point in the short term will not change. (2) The decrease in long-term profits leads to a decrease in the volume of investment in the sector. (3) The decrease in investment in this sector leads to a shortage of supply in the market and thus high prices.

Second, the impact on macroeconomics. Direct stability at the macro level means that the change in the general balance as a result of collecting Zakat will generally start through a change in saving and investment and not through a change in consumption. As for the impact of Zakat distribution, it is clear that it will lead to an increase in the demand for efficient products, and thus their prices will increase, as well as the return on investment in this particular sector. In this sense, resources move from sectors that produce luxury goods to sectors of efficient goods. Therefore, the supply of efficient products increases in the latter sector, which lower their prices again and this cycle continues, resulting in equal net return on investment in both sectors. In cases of resource transfer, this can lead to a change in the returns of labor and capital, as the transfer of resources to labor-intensive sectors leads to an increase in the return of work and a decrease in the return of capital and vice versa. Generally, the application of Zakat cannot harm producers and consumers of efficient goods, and often will lead to improve their relative position at the expense of the producers and consumers of luxury goods.

The overall findings confirm that Zakat plays an important role in establishing social welfare in Saudi Arabia that reflects positively on its economy. This paper contributes to little research produced on the intersections of Muslim 
values, social welfare, economic sustainability, and accounting in the specific context of Saudi Arabia.

\section{References}

Abdelbaki, H. H. (2015). The Impact of Zakat on Income Inequality and Poverty in Malaysia: A Panel Data Analysis. Review of Integrative Business and Economics Research, 2(1), 133-154.

Al-Hweiml, S. (2013). Tax and Zakat Accounting. Riyadh, Kingdom of Saudi Arabia: Institute of Public Administration.

Aliyu, A., Alkali, M., \& Alkali, I. (2016). Islamic Perspective on the Impact of Ethics and Tax for Nigerian Economic Development. International Journal of Islamic Economics and Finance Studies, 2(3), 137-150. https://doi.org/10.12816/0036632

Almunif, A. (1996). Theory and Scientific Application of Tax Accounting and Zakat in the Kingdom of Saudi Arabia. Riyadh, Kingdom of Saudi Arabia: King Saud University.

Al-Suhaibani, M. (1990). Zakat Impact on Economic Resources Utilization. Riyadh, Kingdom of Saudi Arabia: Imam Muhammad bin Saud Islamic University.

Bilo, C., \& Machado, A. (2020). The role of Zakat in the provision of social protection: A comparison between Jordan and Sudan. International Journal of Sociology and Social Policy, 40(3), 236-248. https://doi.org/10.1108/IJSSP-11-2018-0218

Essa, A., \& Aljundi, A. (1985). Zakat on Debts. Journal of Islamic Fiqh Academy, 2(2), 29-46.

General Authority of Zakat and Tax. (2017). Zakaty. Retrieved from https://zakaty.gov.sa/ar/aboutzakat/Pages/default.aspx

Guermat, C., Al-Utaibi, A. T., \& Tucker, J. P. (2003). The Practice of Zakat: An Empirical Examination of Four Gulf Countries. Discussion Papers 0302, University of Exeter, Department of Economics.

Ibrahim, S. M. (2015). The Role of Zakat in Establishing Social Welfare and Economic Sustainability. International Journal of Management and Commerce Innovations, 3(1), 437-441.

Khasandy, E., \& Badrudin, R. (2019). The Influence of Zakat on Economic Growth and Welfare Society in Indonesia. Munich Personal RePEc Archive, 91574, 65-79. https://doi.org/10.33019/ijbe.v3i1.89

Mikesell, J. L. (2003). Fiscal Administration: Analysis and Applications. California, United States: Wadsworth Publishers.

Ministry of Human Resource and Social Development. (2020). Statistics and Information. Retrieved from https://hrsd.gov.sa/en

Oran, A. F. (2016). A Conception to Activate Zakah as an Islamic Mechanism for Human Development. Journal of King Abdulaziz University: Islamic Economics, King Abdulaziz University, Islamic Economics Institute, 29(3), 3-29. https://doi.org/10.4197/Islec.29-3.1

Pryor, F. L. (1985). The Islamic economic system. Journal of Comparative Economics, 9(2), 197-223. https://doi.org/10.1016/0147-5967(85)90039-3

Saudi Organization for Certified Public Accountants. (2016). Standard of Zakat Accounting. Retrieved from https://socpa.org.sa/Socpa/Media-Center/SOCPA-books.aspx

Shaikh, S. A., \& Ismail, A. G. (2017). Role of Zakat in Sustainable Development Goals. International Journal of Zakat, 2(2), 1-9. https://doi.org/10.37706/ijaz.v2i2.21

Suprayitno, E. (2020). The Impact of Zakat on Economic Growth in 5 State in Indonesia. International Journal of Islamic Banking and Finance Research, 4(1), 1-7. https://doi.org/10.46281/ijibfr.v4i1.470

Zalloom, A. (1988). Funds in the Khilafah State. London, United Kingdom: Dar al-ilm lil-Malaayiin.

\section{Copyrights}

Copyright for this article is retained by the author(s), with first publication rights granted to the journal.

This is an open-access article distributed under the terms and conditions of the Creative Commons Attribution license (http://creativecommons.org/licenses/by/4.0/). 